\title{
PERAN SYAHBANDAR DALAM PENEGAKAN HUKUM PENCEMARAN MINYAK DI LAUT OLEH KAPAL TANKER
}

\author{
Elly Kristiani Purwendah \\ Fakultas Hukum Universitas Wijayakusuma Purwokerto \\ e-mail:elly_kristiani@yahoo.co.id \\ Agoes Djatmiko \\ Fakultas Hukum Universitas Wijayakusuma Purwokerto \\ e-mail: agoes-dj@yahoo.co.id
}

\begin{abstract}
ABSTRAK
Penelitian ini menggunakan pendekatan yuridis empiris menggunakan data primer dari wawancara kepada responden. Syahbandar di pelabuhan adalah seorang pejabat pemerintah yang ditunjuk oleh Menteri dengan otoritas tertinggi untuk mengawasi penegakan hukum menjamin keselamatan dan keamanan pelayaran. Salah satu otoritasnya adalah pencegahan dan pengendalian pencemaran minyak di laut oleh kapal tanker. Dalam pelaksanaan akan pengurangan dan pencegahan polusi. Syahbandar memiliki peran utama dalam kewajiban negara sebagai negara berdaulat pesisir, termasuk diantaranya adalah penegakan hukum maritim wilayah administratif, perdata dan pidana. Tugas Syahbandar dalam melakukan pencegahan polusi ini menjabat sebagai Koordinator/Komandan Puskodalok (Pusat Komando dan Lokasi), suatu tim yang terdiri dari Kepolisian, Angkatan Laut, Pertamina (perusahaan gas dan minyak) dan pemerintah daerah. Tim yang dibentuk untuk mengendalikan dan mencegah pencemaran yang disebut Tier 1 telah membatasi kewenangan dengan kategori tumpahan minyak tanggap darurat yang terjadi di dalam atau di luar wilayah Pelabuhan atau minyak dan aktivitas gas atau unit lain yang bisa ditangani oleh infrastruktur, fasilitas dan sumber daya manusia yang tersedia di pelabuhan atau unit minyak dan gas atau unit kegiatan lainnya.
\end{abstract}

Kata Kunci: Syahbandar, pencegahan terhadap pencemaran minyak.

\begin{abstract}
This research was designed by empirical juridical approach study used primary data from an in-depth interview of respondens. Syahbandar at the port was an government official who are appointed by the Minister with a supreme authority to supervise the enforcement of legislation ensuring the safety and security of shipping. One of his authority was the prevention and control of oil pollution at sea by tanker. In the implementation of reduction and prevention pollution, the Syahbandar had a main role as a mandatory in the coastal sovereign state obligation including the maritime law enforcement of administrative, civil, and criminal areas. The task of Syahbandar in conducting pollution prevention served as the coordinator/commander of Puskodalok (Command Control Center at location) teams consisting of the Police, the Navy, the Pertamina (State Oil and Gas Company) and the local government. The teams formed to control and prevention of pollution called Tier 1 had a restrict authority with the categorization of oil spill emergency response occurs inside or outside the Region of Interest Ports Environment (DLKP) and Working Environment Regional Ports (DLKR) or the oil and gas activity or other units that could be handled by the infrastructure, facilities and human resources that available at the port or the oil and gas activity unit or other activity units.
\end{abstract}

Keywords: Syahbandar, prevention of oil pollution. 


\section{PENDAHULUAN}

Konvensi Hukum Laut 1982 merupakan hasil perwujudan dari usaha masyarakat internasional untuk mengatur masalah kelautan secara menyeluruh, masalah perlindungan lingkungan laut dari sumber pencemaran. Salah satu pencemaran lingkungan laut bersumber dari tumpahan minyak oleh kapal tanker, merespon keadaan ini Konferensi Washington di Amerika Serikat pada tahun 1926 mengeluarkan rekomendasi the discharge of oil at sea be limited. ${ }^{1}$

Pengangkutan minyak merupakan hal penting bagi ekonomi dunia dan merupakan bisnis besar. Pengangkutan minyak melalui laut diperkirakan $40 \%$ dari keseluruhan perdagangan yang diangkut melalui laut. Sarana angkutan laut didominasi oleh kapal-kapal tanker yang diperkirakan lebih dari 400 super tanker berlayar setiap harinya. ${ }^{2}$ Kapal-kapal tersebut setiap tahunnya menumpahkan satu sampai dua juta ton minyak di lingkungan laut. Tumpahan minyak ke laut diakibatkan oleh pengoperasian kapal, kecelakaan kapal sehingga mengakibatkan penurunan mutu lingkungan laut. Pencemaran yang terjadi karena pengoperasian kapal tanker diperkirakan mencapai $75 \%$, sedangkan akibat dari kecelakaan kapal hanya $25 \%$ dari total pencemaran yang terjadi. ${ }^{3}$

Untuk dapat mencapai keseimbangan terhadap masalah pencemaran minyak di laut, negara pantai menginginkan terlindunginya lingkungan laut melalui berbagai ratifikasi Konvensi Internasional seperti the International Convention for the Prevention of Pollution from the Ship (yang selanjutnya disebut MARPOL), yang mengatur tentang port authorities dalam hal ini peran Syahbandar dalam menegakkan laut sebagai akibat pencemaran minyak oleh kapal tanker sebagaimana diatur dalam Konvensi Hukum Laut 1982 yang menentukan bahwa penegakkan hukum terhadap pelaku pencemaran lingkungan laut harus dilakukan oleh negara-negara berbendera (flags states), negara pelabuhan (port states) dan negara pantai (coastal states) sebagaimana diatur oleh Pasal 213-220 Konvensi Hukum Laut 1982. Law

\footnotetext{
${ }^{1} \mathrm{http} / / /$ www.amsa.gov.an/me/pn324.HTM, diakses pada 06-06-2000.

${ }^{2}$ Cross, Michael and Mick Hamer, "How to Seal a Supertanker, Improving Ship Design to Prevent Oil Spills", New Scientist, Vol. 133, No. 1812, March, 1992, h. 3-4.

${ }^{3}$ Andre Griffin, "Marpol 73/78 and Vessel Pollution: a Glass Half Four or Half Empty?" Indiana Journal of Global Legal Studies, 1994, h. 1.
}

Enforcement dimaksud yang memiliki kewenangan dalam lini terluar untuk mengamankan lingkungan laut dari pencemaran minyak yang dilakukan oleh kapal tanker adalah Syahbandar sebagai pejabat pemerintah di pelabuhan. Sebagai obyek penelitian dalam penelitian ini adalah Laut Cilacap dengan Pelabuhan Tanjung Intan menjadi lokasi yang sangat menarik untuk melakukan penelitian ini karena seringnya kasus pencemaran minyak oleh kapal tanker terjadi, bahkan dalam kurun waktu dua tahun terakhir dari 2011 sampai dengan 2012 terdapat kasus pencemaran minyak dari tiga kapal tanker, yaitu di tahun 2011 ada dua kasus pencemaran pada bulan Juli dan September oleh Kapal Super Tanker TT. Arenza XXVII dan Kapal MT. Medelin Atlas Belawan IMO 8717245, dan pada bulan April 2012 Kapal MV. Indobaruna V kembali mencemari lingkungan laut Cilacap.

\section{PERUMUSAN MASALAH}

Berdasarkan latar belakang di atas maka penulis merumuskan permasalahan kedudukan syahbandar dalam pelaksanaan keselamatan dan keamanan pelayaran dalam sistem hukum nasional, sebagai berikut: Pertama, Upaya-upaya yang dilakukan Syahbandar dalam penegakan hukum laut pada kasus pencemaran minyak di laut oleh kapal tanker; Kedua, Langkah-langkah apakah yang dilakukan oleh Syahbandar dalam mengantisipasi beberapa kasus pencemaran minyak di Laut Cilacap; Ketiga, Mekanisme koordinasi kerja antara Syahbandar dengan aparat penegak hukum yang lain dalam penegakan hukum kasus pencemaran minyak di laut oleh kapal tanker.

\section{METODE PENELITIAN}

Penelitian ini menggunakan pendekatan teori Lawrence Friedmann sebagai alat uji hipotesis untuk menganalisis peran dari Syahbandar dalam penegakan hukum pencemaran laut oleh kapal tanker di laut Cilacap. Teori Friedmann melihat bahwa keberhasilan penegakan hukum selalu dengan mensyaratkan berfungsinya semua komponen sistem hukum. Sistem hukum dalam pandangan Friedman terdiri dari tiga komponen, yakni komponen struktur hukum (legal structure), komponen substansi hukum (legal substance) dan komponen budaya hukum (legal culture). Struktur hukum (legal structure) 
merupakan batang tubuh, kerangka, bentuk abadi dari suatu sistem. Substansi hukum (legal substance) aturan dan norma aktual yang dipergunakan oleh lembaga-lembaga, kenyataan, bentuk perilaku dari para pelaku yang diamati di dalam sistem. Adapun kultur atau budaya hukum (legal culture) merupakan gagasan-gagasan, sikap-sikap, keyakinan-keyakinan, harapan harapan dan pendapat tentang hukum. ${ }^{4}$

Pendekatan yang digunakan dalam penelitian ini adalah pendekatan yuridis sosiologis, merupakan suatu metode yang mengkaji terhadap hukum sebagai kenyataan yang hidup dalam masyarakat mencakup kenyataan sosial, kenyataan kultur dan lain-lain. ${ }^{5}$ Penelitian ini akan bersifat sebagai penelitian deskriptif dengan menggunakan data kualitatif. Supaya dapat lebih peka dalam menangkap informasi kualitatif, digunakan studi kasus yang berupa status subyek penelitian yang berkenaan dengan suatu fase spesifik atau khas dari keseluruhan personalitas yang berupa, individu, kelompok, dan lembaga atau institusi.

Syahbandar sebagai sasaran tujuan utama dalam penelitian ini akan ditentukan secara purposive sampling, sedangkan sasaran pendukung berupa penyelesaian kasus pencemaran dan antisipasi pemulihan kerugian yang diderita, akan dipilih melalui teknik bola salju (snow ball sampling).

Penelitian ini diharapkan dapat memberikan informasi awal mengenai fakta-fakta penegakkan hukum pencemaran laut oleh kapal tanker, upaya penanggulan dan kendalanya supaya di kemudian hari didapatkan suatu model yang tepat untuk mengantisipasi kasus-kasus pencemaran minyak di masa mendatang.

\section{PEMBAHASAN}

\section{Kedudukan Syahbandar dalam Pelaksanaan Keselamatan dan Keamanan Pelayaran dalam Sistem Hukum Nasional}

Negara Kesatuan Republik Indonesia merupakan negara kepulauan yang disatukan oleh wilayah perairan yang sangat luas dengan batas-batas, hak-hak dan kedaulatan yang ditetapkan dengan undang-undang dan konvensi hukum internasional.

4 W. Friedman, Teori \& Filsafat Hukum, Hukum \& Masalah-Masalah Kontemporer, Susunan III, Rajawali Press, Jakarta, 1977, h. 6-7.

5 Johny Ibrahim, Teori dan Metode Penelitian Hukum Normatif, Bayu Media, Malang, 2006, h. 321.
Daya dukung vitalisasi negara dalam pelaksanakan pembangunan di setiap sektor baik politik, ekonomi, sosial dan budaya diperlukan transportasi nasional yang mudah terakses bagi warga masyarakatnya. Indonesia sebagai negara berdaulat sebagaimana diartikan secara positif oleh Charpentier, ${ }^{6}$ diharapkan dapat di satu sisi dapat mengoptimalisasi segala sumber daya alam yang dimiliki untuk kesejahteraan dan kemakmuran warga negaranya dan disisi lainnya dapat memiliki kewenangan untuk mengatur dan menetapkan kebijakan dalam pengelolaan sumber daya tersebut.

Indonesia dengan kekayaan sumber daya alam hayati maupun non hayati dan kedaulatan yang dimilikinya mengatur urgensitas transportasi laut melalui Undang-Undang Nomor 17 Tahun 2008 tentang Pelayaran (selanjutnya disebut UU Pelayaran) dengan dasar pemikiran tuntutan penyelenggaraan pelayaran sesuai dengan ilmu pengetahuan dan teknologi peran serta swasta dan persaingan usaha, otonomi daerah serta akuntabilitas penyelenggaraan negara dengan tetap mengutamakan keselamatan dan keamanan pelayaran demi kepentingan nasional. Dalam UU Pelayaran ini diatur mengenai pengertian siapakah Syahbandar. ${ }^{?}$

Keselamatan dan keamanan pelayaran meliputi keselamatan dan keamanan angkutan di perairan, dan pelabuhan serta perlindungan lingkungan maritim sebagaimana ditetapkan oleh UU Pelayaran perlu dilaksanakan dengan cermat melalui struktur terkait sebagai pemangku kepentingan dalam hal ini diatur tersendiri secara khusus sebagai penjabaran UU pelayaran melalui Peraturan Menteri Tenaga Kerja Kantor Kesyahbandaran dan Otoritas Pelabuhan (dulu Administrator Pelabuhan yang mengatur jalannya kegiatan pelabuhan dan operasional kapal). ${ }^{8}$

Selanjutnya, Menteri mengatur sepenuhnya tentang segala sesuatu yang bertalian dengan penyelenggaraan pelabuhan dan menunjuk seorang pejabat yang memegang tanggung jawab dan

\footnotetext{
${ }^{6}$ Jean Charpentier, Institutions Internationalle, $13^{\text {rd }}$ edition, Momentos Dalloz, Paris, 1997, h. 25-26.

${ }^{7}$ Syahbandar adalah pejabat pemerintah di pelabuhan yang diangkat oleh Menteri dan memiliki kewenangan tertinggi untuk menjalankan dan melakukan pengawasan terhadap dipenuhinya ketentuan peraturan perundang-undangan untuk menjamin keselamatan dan keamanan pelayaran.

${ }^{8}$ Permen Perhubungan 36 Tahun 2012 rekomendasi ada pada Syahbandar (Hasil wawancara dengan Kasie Keselamatan Berlayar, 12 Mei 2014).
} 
pimpinan umum yaitu Administrator Pelabuhan atau kepala pelabuhan. ${ }^{9}$

Kantor Kesyahbandaran dan Otoritas Pelabuhan (selanjutnya disebut dengan KSOP) merupakan Unit Pelaksana Teknis di lingkungan Kementerian Perhubungan yang berada di bawah dan bertanggungjawab kepada Direktur Jenderal Perhubungan Laut. Tugas yang diemban adalah melaksanakan pengawasan dan penegakan hukum di bidang keselamatan dan keamanan pelayaran, koordinasi kegiatan pemerintahan di pelabuhan serta pengaturan pengendalian dan pengawasan kegiatan kepelabuhanan pada pelabuhan yang diusahakan secara komersial.

Dalam melaksanakan tugas dan fungsinya KSOP menyelenggarakan fungsi: a. melaksanakan pengawasan dan pemenuhan kelaiklautan kapal; b. sertifikasi keselamatan kapal; c. pencegahan pencemaran dari kapal dan penetapan status hukum kapal; d. melaksanakan pemeriksaan manajemen keselamatan kapal; e. melaksanakan pengawasan keselamatan dan keamanan pelayaran terkait dengan kegiatan bongkar muat Barang Berbahaya dan Beracun (selanjutnya disebut B3); f. pengisian bahan bakar; g. ketertiban embarkasi dan debarkasi penumpang; h. pembangunan fasilitas pelabuhan; i. tertib lalu lintas kapal di perairan pelabuhan dan alur pelayaran; j. pemanduan dan penundaan kapal serta penerbitan surat persetujuan berlayar.

Dengan susunan organisasi KSOP meliputi Kepala KSOP (Syahbandar) dalam menjalankan tugasnya didukung oleh struktur organisasi meliputi lingkup administratif dan penegakan hukum. Bagianbagian tersebut adalah; a. sub bagian tata usaha, $b$. seksi status hukum dan sertifikasi kapal, c. seksi keselamatan berlayar, d. penjagaan dan patroli, serta e. seksi lalu lintas dan angkutan laut, serta usaha kepelabuhanan. ${ }^{10}$

Pertama, Pada sub bagian tata usaha dalam menyelenggarakan fungsi untuk mengelola: a. urusan keuangan dan pelaporan sistem akuntansi intansi serta pengelolaan penerimaan negara bukan pajak; b. melaksanakan urusan kepegawaian, pembinaan, pengembangan jabatan fungsional, surat menyurat,

${ }^{9}$ Peraturan Pemerintah Nomor 1 Tahun 1969 Tanggal 18 Januari 1969 tentang Susunan dan Tata Kerja Kepelabuhan dan Daerah.

${ }^{10}$ Hasil wawancara dengan Sie Keselamatan Berlayar, 25 Mei 2014. kearsipan, kerumahtanggaan dan urusan umum; c. melaksanakan pertimbangan dan bantuan hukum serta hubungan masyarakat.

Kedua, Pada sub bagian umum dan hubungan masyarakat mempunyai fungsi untuk melakukan urusan surat menyurat, kearsipan, kerumahtanggaan dan urusan umum, pertimbangan dan bantuan hukum serta hubungan masyarakat penyusunan dan sosialisasi peraturan kepelabuhan.

Ketiga, Bidang status hukum dan sertifikasi kapal mempunyai tugas melaksanakan pemeriksaan, pengujian dan sertifikat kelaiklautan, keselamatan kapal, pencegahan pencemaran dari kapal dan manajemen keselamatan kapal serta penetapan status hukum kapal.

Keempat, Seksi sertifikasi kapal memiliki peran fungsi yang salah satunya adalah melaksanakan pemeriksaan peralatan pencegahan pencemaran dan pembersihan tangki serta verifikasi manajemen keselamatan dan pencegahan pencemaran dari kapal. Selain itu seksi sertifikasi kapal memiliki tugas sampai kepada pembersihan kapal serta perlindungan ganti rugi pencemaran.

Kelima, Bidang yang penting terkait dengan pencegahan dan penanggulangan pencemaran adalah Bidang Keselamatan Berlayar, Penjagaan dan Patroli yang mempunyai tugas melaksanakan pengawasan tertib lalu lintas kapal di perairan pelabuhan dan alur pelayaran, pemanduan dan penundaan kapal, penerbitan surat persetujuan berlayar, kegiatan alih muat di perairan pelabuhan, salvage dan pekerjaan bawah air, bongkar muat barang berbahaya, barang khusus, pengisian bahan bakar, limbah B3, ketertiban embarkasi dan debarkasi penumpang, pembangunan fasilitas pelabuhan, pengerukan dan reklamasi, pelaksanaan bantuan pencarian dan penyelamatan (Search and Rescue/SAR), pengendalian dan koordinasi penanggulangan pencemaran serta pemadaman kebakaran di pelabuhan, pelaksanaan perlindungan lingkungan maritim, pelaksanaan pemeriksaan dan verifikasi sistem keamanan kapal dan fasilitas pelabuhan (International Ship and Port Facility Security Code/SPS Code), pemeriksaan pendahuluan pada kecelakaan kapal, penegakan hukum di bidang keselamatan dan keamanan pelayaran serta pelaksanaan koordinasi kegiatan pemerintahan di pelabuhan yang terkait dengan pelaksanaan pengawasan dan penegakan hukum di bidang keselamatan dan keamanan pelayaran. 
Syahbandar dalam melaksanakan tugas terhadap perlindungan lingkungan maritim ${ }^{11}$ dari kegiatan pencemaran, ${ }^{12}$ baik pencegahan maupun penanggulangan pencemaran dalam pelaksanaannya secara mekanisme struktural kinerja organisatoris didukung oleh bidang tersebut di atas. Seksi tersebut menyelenggarakan fungsi secara administratif berbicara tentang perijinan yang merepresentasikan peran fungsi kewenangan negara dalam memberikan surat persetujuan berlayar untuk keluar dan masuk wilayah negara. Bidang ini berfungsi melaksanakan pengawasan tertib bandar dan tertib berlayar, lalu lintas keluar masuk kapal, pergerakan kapal (shifting), pemanduan dan penundaan kapal; pelaksanaan pengawasan pemenuhan persyaratan kelaiklautan kapal; pelaksanaan penerbitan surat persetujuan berlayar; pelaksanaan pengawasan kapal asing (port state control dan flag state control); melaksanakan pengawasan kegiatan bongkar muat barang khusus dan barang berbahaya dan pengisian bahan bakar serta limbah B3, pembangunan fasilitas pelabuhan serta pengerukan dan reklamasi; melaksanakan patroli di perairan pelabuhan, pengawasan dan pengamanan terhadap keselamatan kapal yang masuk keluar pelabuhan, kapal sandar dan berlabuh; menyiapkan bahan koordinasi dan pemberian bantuan pencarian dan penyelamatan (Search and Rescue/SAR), penanggulangan pencemaran laut serta pencegahan dan pemadaman kebakaran di perairan pelabuhan serta pengawasan perlindungan lingkungan maritim; melaksanakan pengawasan kegiatan alih muat di perairan pelabuhan, salvage dan pekerjaan bawah air; melaksanakan pemeriksaan dan verifikasi sistem keamanan kapal dan fasilitas pelabuhan (International Ship and Port Facility Security Code/ISPS-Code); menyiapkan bahan

${ }^{11}$ Definisi hukum lingkungan terkait dengan dua aspek, pertama terkait ruang lingkup subjek hukum dan kompetensi kelembagaannya; kedua, terkait pertanggungjawaban terhadap kerusakan lingkungan,

${ }^{12}$ Komar Kantatmadja berpendapat mengutip dari Muchtar Kusumaatmadja, Pencemaran, Laut dan Pengaturan Hukumnya, Universitas Padjajaran, Bandung, 1977, h. 5. Pencemaran laut adalah telah terjadinya perubahan lingkungan laut yang terjadi sebagai akibat dimasukkannya oleh manusia secara langsung maupun tidak langsung bahan-bahan atau energi ke dalam lingkungan laut yang menghasilkan akibat yang demikian buruknya sehingga merupakan kerugian bagi kekayaan hayati, bahaya terhadap kesehatan manusia, gangguan terhadap kegiatan di laut termasuk perikanan, penggunaan air laut yang wajar, pemburukan daripada kualitas laut dan menurunnya kualitas tempat pemukiman dan rekreasi. pemeriksaan pendahuluan pada kecelakaan kapal dan melaksanakan penyidikan tindak pidana di bidang pelayaran sesuai peraturan perundang-undangan.

Syahbandar dalam pelaksanaan tugas dalam mempertahankan kedaulatan wilayah laut negara mendasarkan kepada sistem hukum nasional terkait hukum laut, yang sebagian besar merupakan hasil ratifikasi dari konvensi internasional. Ratifikasi yang mendasari sistem hukum nasional yaitu: a. Undang-Undang Nomor 17 Tahun 1985 tentang Ratifikasi UNCLOS; b. UU Pelayaran; c. Peraturan Pemerintah Nomor 19 Tahun 1999 tentang Pengendalian Pencemaran dan/atau Perusakan Laut; d. Peraturan Pemerintah Nomor 21 Tahun 2010 tentang Perlindungan Lingkungan Maritim; e. Peraturan Presiden Nomor 109 Tahun 2006 tentang Penanggulangan terhadap Keadaan Darurat Tumpahan Minyak di Laut; f. Keppres Nomor 52 Tahun 1999 tentang Pengesahan CLC 1969; g. Keputusan Presiden Nomor 65 Tahun 1980 tentang Ratifikasi SOLAS 1974; h. Keputusan Presiden Nomor 46 Tahun 1986 tentang Ratifikasi MARPOL 73/78; i. Peraturan Menteri Perhubungan Nomor PM 36 Tahun 2012 tentang Organisasi dan Tata Kerja Kantor Kesyahbandaran dan Otoritas Pelabuhan; j. Peraturan Menteri Perhubungan Nomor PM 58 Tahun 2013 tentang Penanggulangan Pencemaran di Perairan dan Pelabuhan; dan k. Resolusi IMO Nomor A741 (18) tentang ISM-Code.

Syahbandar melaksanakan tugas mengamankan teritori wilayah laut berdasarkan kewajiban negara dan kedaulatan negara pantai yang diamanatkan oleh UNCLOS sebagai Konvensi tentang Hukum Laut Internasional yang sudah diratifikasi menjadi hukum nasional. Kedudukan Syahbandar dalam konsepsi hukum laut internasional sebagai commander atau leading sector utama untuk menjaga keselamatan dan keamanan wilayah negara dalam hal ini wilayah lingkungan laut. Kedudukan dan peran syahbandar dalam sistem penegakan hukum laut Indonesia sangat strategis mengingat wilayah yang ditegakkan meliputi sisi administratif terkait persyaratan administratif, surat menyurat, perijinan dan lain-lain berhubungan dengan ketatausahaan kepelabuhan dan teritori laut, kemudian penegakan wilayah perdata dan pidana terkait ganti kerugian dan denda atau sanksi badan.

Dalam tataran praktis di lapangan, Konvensi Hukum Laut belum dipahami sekali dalam tataran 
praktek hukum karena ratifikasi ini hanya melalui Keppres, sedangkan dalam sistem hukum nasional mengenai hirarki peraturan perundang-undangan. Undang-undang memiliki posisi yang lex superior dalam hal ini adalah Undang-Undang Pelayaran. Dalam tataran praktis, Konvensi Hukum Laut tidak dikenal dan lebih dikenal konvensi yang telah diratifikasi yaitu SOLAS yang mengatur keselamatan kapal komersial dan IMO. Instrumen CLC yang telah diratifikasi, belum mendapatkan porsi untuk digunakan sebagai standar perhitungan ganti kerugian di dalam praktek. Padahal Indonesia telah meratifikasi konvensi CLC tapi sementara ini belum dikenal dalam tataran praktek penegakan hukum laut dalam hal terjadi pencemaran minyak di laut. ${ }^{13}$

\section{Peran dan Fungsi Syahbandar dalam Pencegahan dan Pengendalian Pencemaran Minyak di Laut oleh Kapal Tanker}

Peran dan fungsi Syahbandar yang diamanatkan melalui UU Pelayaran, Syahbandar berfungsi mengamankan transportasi laut. Dalam melaksanakan tugas penegakan hukum laut Syahbandar memiliki beberapa fungsi, yaitu fungsi administratif dalam penegakan administratif perijinan transportasi laut, melaksanakan peran dan fungsi penegakan hukum laut dalam hal terjadi kecelakaan kapal karena ketidaklaik laut kapal atau dalam hal terjadinya pencemaran laut oleh kapal termasuk dalam hal ini adalah pencemaran minyak oleh kapal tanker. ${ }^{14}$

Peran Syahbandar terhadap penanggulangan terhadap keadaan darurat akibat tumpahan minyak di laut oleh kapal tanker diatur dalam Peraturan Presiden Nomor 109 Tahun 2006 tentang Penanggulangan Keadaan Darurat Tumpahan Minyak di Laut. Pemikiran pegaturan ini karena kegiatan pelayaran, kegiatan pengusahaan minyak dan gas bumi serta kegiatan lainnya mengandung risiko terjadinya kecelakaan yang dapat mengakibatkan terjadinya tumpahan minyak yang dapat merugikan lingkungan laut sehingga memerlukan tindakan penanggulangan secara cepat, tepat dan terkoordinasi ${ }^{15}$ Pemerintah

13 Hasil wawancara dengan Kasie Keselamatan Berlayar, Senin, 12 Mei 2014.

${ }^{14}$ Hasil wawancara dengan Sie Keselamatan Berlayar, 25 Mei 2014.

${ }^{15}$ Sehubungan dengan telah diundangkannya UndangUndang Nomor 7 Tahun 1985 tentang Pengesahan United Nations Conventions on the Law of the Sea.
Indonesia berkewajiban dengan mengembangkan suatu kebijakan dan mekanisme cepat dan tepat serta terkoordinasi dalam penanggulangan tumpahan minyak di laut dan penanggulangan dampak lingkungan akibat tumpahan minyak di laut dengan mengerahkan potensi lokal, wilayah dan nasional secara efektif.

Penanggulangan keadan darurat tumpahan minyak di laut diperlukan sebagai sebuah tindakan cepat, tepat dan terkoordinasi untuk mencegah dan mengatasi penyebaran tumpahan minyak di laut. Syahbandar berperan mengatur jalannya kegiatan pelabuhan dan otoritas pelabuhan dan operasional kapal melalui rekomendasi Syahbandar. Syahbandar sebagai pejabat yang menjadi leading sector dalam keselamatan berlayar transportasi laut dan sebagai mandatory negara. ${ }^{16}$

Dalam melaksanakan keselamatan berlayar kapal tanker, Syahbandar berkoordinasi dengan Pertamina sebagai pengelola dermaga, dimana Syahbandar memberikan ijin untuk melakukan kegiatan dermaga dan kapal tanker sebagai kapal yang dicharter oleh pihak Pertamina sebagai pengelola dermaga. Setelah mendapat persetujuan dari Syahbandar, kapal asing dari karantina kesehatan setelah dipastikan dalam seluruh awaknya dalam kondisi sehat, kemudian dari imigrasi Kementrian Hukum dan HAM memenuhi prosedural formal keimigrasian dan terpenuhinya persyaratan bea dan cukai maka kapal tersebut oleh pilot pandu dari kontrol negara pantai (port state control) diperiksa oleh Syahbandar sebagai clearent terakhir. Syahbandar naik ke kapal tanker asing sebagai clearent terakhir setelah semua instansi terkait naik ke atas untuk memeriksa administratif perijinan masuk dalam kedaulatan negara.

Syahbandar selaku koordinator di Daerah Lingkungan Kerja (DLKR) dan Daerah Lingkungan Kepentingan (DLKP) memiliki struktur tugas dalam organisasi yang dibentuk melalui hukum positif dalam hal ini melalui Peraturan Menteri Perhubungan Nomor PM 36 Tahun 2012 tentang Organisasi dan Tata Kerja Kantor Kesyahbandaran dan Otoritas Pelabuhan, dimana kantor KSOP Cilacap berdasarkan klasifikasi ada pada klasifikasi KSOP.

Syahbandar dalam melaksanakan keamanan dan keselamatan berlayar dalam hal pencemaran minyak

${ }^{16}$ Hasil wawancara dengan sie Keselamatan Berlayar, 25 Mei 2014. 
oleh kapal tanker mendasarkan pada dokumen Marine Pollution (MARPOL), dimana setiap kapal tanker wajib memiliki sertifikat CLC 1969 dan Fund 1992. CLC bunker diwajibkan sebagai pengaman bagi negara pantai dalam hal menerima kapal tanker yang masuk dalam kedaulatan wilayahnya, untuk antisipasi dan proteksi apabila terjadi force majeur dengan akibat pencemaran lingkungan karena CLC yang berkantor di Singapura. ${ }^{17}$

Fungsi, Tugas, dan Kewenangan Syahbandar adalah melaksanakan fungsi keselamatan dan keamanan pelayaran yang mencakup, pelaksanaan, pengawasan dan penegakan hukum di bidang angkutan di perairan, kepelabuhanan, dan perlindungan lingkungan maritim di pelabuhan, selain itu Syahbandar melaksanakan tugas dan fungsi membantu pelaksanaan pencarian dan penyelamatan (Search and Rescue/SAR) di pelabuhan sesuai dengan ketentuan peraturan perundang-undangan. Syahbandar diangkat oleh Menteri yang memenuhi persyaratan kompetensi di bidang keselamatan dan keamanan pelayaran serta kesyahbandaran. Dalam melaksanakan fungsi keselamatan dan keamanan Syahbandar mempunyai tugas dan fungsi, mengawasi kelaiklautan kapal, keselamatan, keamanan dan ketertiban di pelabuhan; mengawasi tertib lalu lintas kapal di perairan pelabuhan dan alur-pelayaran; mengawasi kegiatan alih muat di perairan pelabuhan; mengawasi kegiatan salvage dan pekerjaan bawah air; mengawasi kegiatan penundaan kapal; mengawasi terhadap pemanduan; mengawasi bongkar muat barang berbahaya serta limbah bahan berbahaya dan beracun; mengawasi pengisian bahan bakar; mengawasi ketertiban embarkasi dan debarkasi penumpang; mengawasi pengerukan dan reklamasi; mengawasi kegiatan pembangunan fasilitas pelabuhan; melaksanakan bantuan pencarian dan penyelamatan; memimpin penanggulangan pencemaran dan pemadaman terhadap kebakaran di pelabuhan; dan mengawasi pelaksanaan perlindungan lingkungan maritim.

Dalam melaksanakan penegakan hukum di bidang keselamatan dan keamanan Syahbandar melaksanakan tugas sebagai Pejabat Penyidik Pegawai Negeri Sipil sesuai dengan ketentuan peraturan perundang-undangan.

${ }^{17}$ Hasil wawancara dengan sie Keselamatan Berlayar, 25 Mei 2014.
Peran Syahbandar dalam pengawasan keamanan dan keselamatan berlayar kapal tanker di wilayah Indonesia, adalah pihak keagenan kapal tanker via surat melaporkan rencana kedatangan maksimal 1×24 jam. Setelah laporan tersebut valid berikut dengan jadwal kedatangannya diinfokan kepada kepanduan atau navigasi agar mereka dapat menempatkan area labuh jangkar (anchorage area) yang posisinya sudah diploting di peta. ${ }^{18}$

Setelah itu keagenan baru mengirimkan surat kepada Syahbandar untuk mendapatkan ijin masuk (clearent in). Syahbandar secara organisatoris hirarkial (sebagai struktur hukum yang berperan merepresentasikan mandatory negara) mendasarkan kepada sistem hukum nasional dalam hal ini UU Pelayaran berkewajiban untuk menyelenggarakan perlindungan lingkungan maritim dilakukan oleh Pemerintah untuk menyelenggarakan perlindungan terhadap lingkungan maritim melalui pencegahan dan penanggulangan pencemaran dari pengoperasian kapal; dan pencegahan dan penanggulangan pencemaran dari kegiatan kepelabuhanan. Selain Syahbandar wajib melakukan perlindungan terhadap lingkungan maritim terhadap, pembuangan limbah di perairan; dan penuntunan kapal.

Syahbandar dalam melakukan perlindungan maritim memiliki kewenangan untuk menegakkan hukum melalui penerapan sanksi pidana yang sebagaimana dicantumkan secara tegas dalam Pasal 303 UU Pelayaran menegaskan bahwa, setiap orang yang mengoperasikan kapal dan pelabuhan tanpa memenuhi persyaratan keselamatan dan keamanan pelayaran serta perlindungan lingkungan maritim sebagaimana dimaksud dalam Pasal 122 dipidana dengan pidana penjara paling lama 2 (dua) tahun dan denda paling banyak Rp 300.000.000,00 (tiga ratus juta rupiah). Jika perbuatan sebagaimana dimaksud pada ayat (1), mengakibatkan kerugian harta benda dipidana dengan pidana penjara paling lama 4 (empat) tahun dan denda paling banyak Rp 500.000.000,00 (lima ratus juta rupiah). Jika perbuatan sebagaimana dimaksud mengakibatkan kematian seseorang, dipidana dengan pidana penjara paling lama 10 (sepuluh) tahun dan denda paling banyak Rp 1.500.000.000,00 (satu miliar lima ratus juta rupiah).

${ }^{18}$ Hasil wawancara dengan sie Keselamatan Berlayar, 25 Mei 2014. 
Dalam melaksanakan fungsi dan tugas Syahbandar mempunyai kewenangan sebagai berikut: a. mengkoordinasikan seluruh kegiatan pemerintahan di pelabuhan; b. memeriksa dan menyimpan surat, dokumen, dan warta kapal; c. menerbitkan persetujuan kegiatan kapal di pelabuhan; e. melakukan pemeriksaan terhadap kapal; f. menerbitkan Surat Persetujuan Berlayar; g. melakukan pemeriksaan kecelakaan kapal; $h$. menahan kapal atas perintah pengadilan; dan i. melaksanakan Sijil Awak Kapal.

Syahbandar dalam menentukan kapal tanker yang dapat masuk wilayah Indonesia mendasarkan pada rekomendasi dari Biro Klasifikasi Indonesia (BKI) yang menentukan kelas atau klasifikasi kapal yang boleh beroperasi di Indonesia. Ini terkait dengan kelaiklautan kapal yang secara standarisasi memenuhi persyaratan memiliki penanggulangan pencemaran, memiliki gas buang dan lain-lain. Meskipun adakalanya di dalam praktek secara administrasi terkadang prosedur dan persyaratan tidak dipenuhi secara rigid karena adanya dispensasi untuk kapal dalam keadaan tertentu. Seharusnya hanya kapal di atas tahun 1992 yang memiliki fasilitas double bottom dan double hull yang dianggap laik laut yang diijinkan untuk masuk pelabuhan (port state), namun pada kenyataannya di bawah kondisi standar tersebut diijinkan karena memiliki dispensasi.

Mekanisme Kerja Syahbandar dan Koordinasi dengan Struktur Hukum dalam Pengendalian Pencemaran Minyak di Laut oleh Kapal Tanker

Syahbandar dalam melaksanakan pengendalian pencemaran minyak oleh kapal tanker bekerja secara terorganisatoris bersama unsur pemerintahan yang lain sebagai struktur hukum terkait penegakan hukum laut, dengan mekanisme yang sistematis sebagaimana diatur oleh UU Pelayaran, Peraturan Presiden Nomor 109 Tahun 2006 dan Peraturan Menteri Perhubungan Nomor 58 Tahun 2013.

Menurut Sumber data primer dari Sie Keselamatan Berlayar (25 Juni 2014), saat terjadi pencemaran Syahbandar sebagai commander atau koordinator penanggulangan pencemaran melaporkan kapal kepada keagenan kapal dan Syahbandar akan minta keagenan untuk menanggulangi pencemaran tersebut dengan SOP (Standar Operasional Prosedur) untuk wilayah pencemaran yang terjadi. Commander dalam hal ini Syahbandar sebagai koordinator akan menggerakkan tim penanggulangan pencemaran dari Kasie Keselamatan Berlayar, Penjagaan dan Patroli bekerjasama dengan Kepolisian, TNI-AL, dan instansi terkait seperti Pemerintah Daerah dengan lembaga terkait dan Pertamina sebagai pengusaha minyak. Laporan pencemaran dilakukan oleh Syahbandar kepada Kapolres, Komandan AL, Pemerintah Daerah untuk kemudian dibentuk Puskodalok (Pusat Komando Pengendalian Lokasi). Koordinasi tersebut di dalam sistem komando Syahbandar bertempat di kantor Syahbandar dan Pertamina.

Dalam penanggulangan pencemaran dibuat gugus tugas pengendalian terhadap pencemaran yang disebut sebagai Tier. Ada tiga klasifikasi Tier dalam pengendalian pencemaran, Tier 1 untuk teknik pengembangan pencemaran wilayah lokal. Dalam rangka penanggulangan keadaan darurat tumpahan minyak di laut Tier 1 terdiri dari ADPEL atau KAKANPEL atau pimpinan unit pengusaha minyak dan gas bumi atau penanggungjawab kegiatan lain wajib membentuk Tim Lokal Penanggulangan Keadaan Darurat Tumpahan minyak di laut yang biasa disebut dengan tim lokal.

Dari data primer diketahui keterlibatan pengusaha minyak dalam penanggulangan terhadap pencemaran terutama dalam hal fasilitas baik sarana maupun prasarana. Hal ini terutama dalam sarana prasarana kapal karena kondisi kapal KSOP tidak sesuai dengan kondisi geografis laut Cilacap, selain itu pemeriksaan sampel tercemar juga masih menggunakan fasilitas laboratorium pertamina yang tentu saja independensi dan akurasinya validitasnya perlu untuk di cross check ulang untuk validitas hasilnya. Keadaan ini dimungkinkan terjadi karena hukum positif mengatur biaya penanggulangan yang memang dibebankan kepada pemilik atau operator kapal, pimpinan tertinggi pengusaha minyak dan gas bumi atau penanggungjawab tertinggi kegiatan pengusahaan minyak lepas pantai atau pimpinan penanggungjawab kegiatan lain yang karena kegiatannya mengakibatkan terjadinya tumpahan minyak di laut bertanggungjawab mutlak atas biaya, penanggulangan tumpahan minyak di laut, penanggulangan dampak lingkungan akibat tumpahan minyak di laut, kerugian masyarakat akibat tumpahan minyak di laut, dan kerugian lingkungan akibat tumpahan minyak di laut. 
Perhubungan laut sendiri selalu merefresh institusinya untuk selalu melakukan pelatihan penanggulangan pencemaran laut secara nasional secara periodik setiap dua tahun dengan agenda MARPOL exercise di Kementrian Perhubungan Laut dimana Direktorat Jenderal Perhubungan Laut sebagai mission commander dilakukan secara bergiliran di pelabuhan dengan Pertamina.

Dalam penanggulangan pencemaran minyak setiap pelabuhan negara pantai seharusnya memiliki sarana pelabuhan penanggulangan pencemaran (port facilities). Dalam wilayah Cilacap, Pelindo tidak memiliki port facilities sehingga penanggulangan pencemaran menggunakan alat Pertamina. Ternyata permasalahan dalam penegakan hukum pencemaran minyak oleh kapal tanker terkait peran Syahbandar masih terkendala permasalahan sarana prasarana terkait dengan sarana kapal Syahbandar, laboratorium penentu ambang batas pencemaran yang independen dan fasilitas pelabuhan penanggulangan pencemaran.

\section{PENUTUP}

\section{Kesimpulan}

Berdasarkan penelitian yang telah dilakukan selama ini dapat disimpulkan, bahwa:

Pertama, Peran Syahbandar sebagaimana diatur dalam UU Pelayaran adalah melakukan penegakan hukum di wilayah teritorial laut baik secara administratif perijinan, maupun preventif dan represif meliputi pemberian sanksi keperdataan (ganti kerugian) dan sanksi pidana (denda dan kurungan) secara terintegrasi dengan aparat penegak hukum yang lain dalam hal terjadi pencemaran minyak di laut oleh kapal tanker. Syahbandar dalam konsepsi hukum laut internasional sebagai commander/ leading sector utama untuk menjaga keselamatan dan keamanan wilayah negara dalam hal ini wilayah lingkungan laut. Peran Syahbandar dalam sistem penegakan hukum laut Indonesia sangat strategis mengingat wilayah yang ditegakkan meliputi sisi administratif terkait persyaratan administratif, surat-menyurat, perijinan dan lain-lain berhubungan dengan ketatausahaan kepelabuhan dan teritorial laut, kemudian penegakan wilayah perdata dan pidana terkait ganti kerugian dan denda atau sanksi badan.

Syahbandar melakukan penegakan hukum laut dalam hal terjadi pencegahan dan penanggulangan pencemaran minyak oleh kapal tanker berperan sebagai commander, mengkoordinasi berbagai institusi untuk melakukan berbagai hal supaya pencemaran tersebut tidak berdampak semakin luas.

Kedua, Upaya pencegahan yang dilakukan oleh Syahbandar dalam menanggulangi pencemaran minyak di laut oleh kapal tanker melalui mekanisme pengawasan pencegahan pencemaran dengan kontrol terhadap peralatan pencegahan dan penanggulangan pencemaran kapal tanker yang masuk ke wilayah RI, apabila kapal tanker tersebut tidak bisa mengantisipasi pencemaran tersebut, Syahbandar dan tim yang terbentuk akan menanggulangi pencemaran dengan sarana prasarana yang dimiliki pengusaha minyak dalam hal ini pertamina, menurut ketentuan, seharusnya pelabuhan memiliki sarana pelabuhan pencegahan dan penanggulangan pencemaran, dalam praktek fasilitas tersebut tidak dimiliki oleh pelabuhan.

Syahbandar dalam berupaya untuk menghindari pencemaran minyak di laut oleh kapal tanker melakukan pemeriksaan administratif kapal tanker melalui kelengkapan sarana prasarana kapal terhadap standarisasi pencemaran yang dimiliki oleh kapal tanker. Kapal tanker yang dapat masuk wilayah Indonesia mendasarkan pada rekomendasi dari Biro Klasifikasi Indonesia (BKI) yang menentukan kelas atau klasifikasi kapal yang boleh beroperasi di Indonesia. Ini terkait dengan kelaiklautan kapal yang secara standarisasi memenuhi persyaratan memiliki penanggulangan pencemaran, memiliki gas buang dan lain-lain.

Meskipun adakalanya di dalam praktek secara administrasi terkadang prosedur dan persyaratan tidak dipenuhi secara rigid karena adanya dispensasi untuk kapal dalam keadaan tertentu. Seharusnya hanya kapal di atas tahun 1992 yang memiliki fasilitas double bottom dan double hull yang dianggap laik laut yang diijinkan untuk masuk pelabuhan (port state), namun pada kenyataannya di bawah kondisi standar tersebut diijinkan karena memiliki dispensasi.

Ketiga, Langkah yang diambil oleh Syahbandar pada saat terjadi pencemaran adalah dibentuknya tim gugus tugas Syahbandar sebagai commanderkoordinator penanggulangan pencemaran melaporkan kapal kepada keagenan kapal dan Syahbandar akan minta keagenan untuk menanggulangi pencemaran tersebut dengan SOP (Standar Operasional Prosedur) untuk wilayah pencemaran yang terjadi. 
Commander dalam hal ini Syahbandar sebagai koordinator akan menggerakkan tim penanggulangan pencemaran dari Kasie Keselamatan Berlayar, Penjagaan dan Patroli bekerjasama dengan Kepolisian, TNI AL, dan instasi terkait seperti Pemerintah Daerah dengan lembaga terkait dan Pertamina sebagai Pengusaha minyak. Laporan pencemaran dilakukan oleh Syahbandar kepada Kapolres, Komandan AL, Pemerintah Daerah untuk kemudian dibentuk Puskodalok (Pusat Komando Pengendalian Lokasi). Koordinasi tersebut di dalam sistem komando Syahbandar bertempat di kantor Syahbandar dan Pertamina.

Dalam penanggulangan pencemaran dibuat gugus tugas pengendalian pencemaran yang disebut sebagai Tier. Ada tiga klasifikasi Tier dalam pengendalian pencemaran, Tier 1 untuk tehnik pengembangan pencemaran wilayah lokal. Dalam rangka penanggulangan keadaan darurat tumpahan minyak di laut Tier 1 terdiri dari ADPEL atau KAKANPEL atau pimpinan unit pengusaha minyak dan gas bumi atau penanggung jawab kegiatan lain wajib membentuk Tim Lokal Penanggulangan Keadaan Darurat Tumpahan minyak di laut yang biasa disebut dengan tim lokal.

Keempat, Mekanisme koordinasi kerja antara Syahbandar dengan aparat penegak hukum yang lain dalam hal ini Kepolisian, TNI AL, ADPEL, Pemerintah Daerah yang tergabung dalam Pusat Komando Pengendalian Lokasi (Pusdalok). Syahbandar bertugas sebagai Pejabat Penyidik Pegawai Negeri Sipil sesuai dengan ketentuan peraturan perundang-undangan. Syahbandar bertindak sebagai koordinator misi (commander), dalam hal ini sebagai pejabat yang bertanggungjawab atas penyelenggaraan operasi penanggulangan keadaan darurat tumpahan minyak di laut oleh kapal tanker

\section{Rekomendasi:}

Peran Syahbandar dalam melaksanakan wewenang dan tugas serta fungsinya untuk penanggulan terhadap pencemaran minyak oleh kapal tanker di wilayah laut harus didukung dengan payung hukum tersendiri (khusus) yang tidak berseberangan dengan peraturan perundangundangan lainnya.

\section{DAFTAR PUSTAKA}

\section{Peraturan Perundangan-undangan:}

Undang-Undang Republik Indonesia Nomor 17 Tahun 1985 tentang Ratifikasi UNCLOS 1982. Undang-Undang Republik Indonesia Nomor 17 Tahun 2008 tentang Pelayaran.

Peraturan Pemerintah Nomor 1 Tahun 1969 tentang Susunan dan Tata Kerdja Kepelabuhanan dan Daerah Pelajaran.

Peraturan Pemerintah Nomor 19 Tahun 1999 tentang Pengendalian Pencemaran dan/atau Perusakan Laut.

Peraturan Pemerintah Nomor 21 Tahun 2010 tentang Perlindungan Lingkungan Maritim.

Peraturan Presiden Nomor 109 Tahun 2006 tentang Penanggulangan Keadaan Darurat Tumpahan Minyak di Laut.

Keputusan Presiden Republik Indonesia Nomor 52 Tahun 1999 tentang Pengesahan CLC 1969.

Keputusan Presiden Republik Indonesia Nomor 65 Tahun 1980 tentang Ratifikasi SOLAS 1974.

Keputusan Presiden Republik Indonesia Nomor 46 Tahun 1986 tentang Ratifikasi MARPOL 73/78. Peraturan Menteri Perhubungan Nomor PM 36 Tahun 2012 tentang Organisasi dan Tata Kerja Kantor Kesyahbandaran dan Otoritas Pelabuhan.

Peraturan Menteri Perhubungan Nomor PM 58 Tahun 2013 tentang Penanggulangan Pencemaran di Perairan dan Pelabuhan.

Resolusi IMO Nomor A741 (18) tentang ISM-Code. United Nation on The Law of The Sea (UNCLOS 1982).

Convention on Liability for Oil Pollution Damage 1969.

Protocol 1992 (CLC 1969).

Liabillity Convention 1972 "The Convention on International Liability for Damage Cause by Space Object 1972”.

\section{Buku:}

Charpentier, Jean. 1997. Institutions internationales. $13^{\text {rd }}$ edition. Paris: Momentos Dalloz.

Friedmann, W. 1990. Teori \& Filsafat Hukum, Hukum \& Masalah-Masalah Kontemporer, Susunan III. Jakarta: Rajawali Press. Ibrahim, Johny. 2006. Teori dan Metode Penelitian Hukum Normatif. Malang: Bayumedia.

Konvensi Jenewa 1958 "Convention on The Territorial Sea and Contiguous Zone". Nikson 
S., Willem. 2009. Kebijakan Keselamatan

Transportasi Laut. Jakarta: Badan Koordinasi

Keamanan Laut.

Konvensi Jenewa 1958. "Convention on The

Territorial Sea and Contiguous Zone”. Nikson

S., Willem. 2009. Kebijakan Keselamatan

Transportasi Laut. Jakarta: Badan Koordinasi

Keamanan Laut.

Kusumaatmadja, Mochtar. 1977. Pencemaran

Laut dan Pengaturan Hukumnya. Bandung: Universitas Padjajaran.

\section{Jurnal Penelitian:}

Cross, Michael and Mick Hamer, "How to Seal a Supertanker, Improving Ship Design to Prevent Oil Spills", New Scientist, Vol. 133, No. 1812, March, 1992.

Griffin, Andrew. 1994. "Marpol 73/78 and Vessel Pollution: a Glass Half Full or Half Empty?". Indiana Journal of Global Legal Studies.

\section{Website dan Lain-lain:}

Australian Maritime Safety Authority. 06-06-2000, http://www.amsa.gov.nav.me/pn324.htm.

IMO and Maritime Security. International Maritime Orgnization. 1986. Superintendent of Documents Department of State Bulletin.

IMO-index of convention, 24-02-2000, http://www. imo.org/imo/convent/index.htm

IMOs Website-Summary of Status of Convention, 24-06-200, http://www.imo.org/convent/ summary.htm

Marine Pollution, (26-06-2000), http://www.imo. org/imo/convent/pollute.htm Ports, Maritime \& Logistics: Marine Pollution Prevention, (608-2000).

http://www.world-bank.org/htmi/tpd/transport/ports/ mar-poll.htm. 